Pediat. Res. 4: 389-397 (1970)

Infants

nitrogen metabolism

premature infants protein synthesis

urea

\title{
Rate of Protein Synthesis in Premature Infants
}

\author{
JoHN F. NichOLSON ${ }^{[28]}$ \\ Babies Hospital and the Department of Pediatrics, College of Physicians and Surgeons, \\ Columbia University, New York, New York, USA
}

\begin{abstract}
Extract
Estimated by the method of SAN Pietro and Rittenberg the metabolic fool of nitrogen was found to contain $0.315,0.338$, and $0.560 \mathrm{~g} \mathrm{~N}$ and to turn over $15.1,13.5$, and 12.1 times/24 $\mathrm{h}$ in three premature infants. Their rates of protein synthesis were $4.2,3.9$, and $5.9 \mathrm{~g}$ protein $\mathrm{N} / 24 \mathrm{~h}$.

In the first $24 \mathrm{~h}$ after ingestion, less than $1.5 \%$ of the dose of ${ }^{15} \mathrm{~N}$ appeared as fecal nitrogen which accounted for $6.8,10.9$, and $9.0 \%$ of the total ${ }^{15} \mathrm{~N}$ excreted during this period. Inclusion of fecal nitrogen in the SAN Pietro-Rittenberg calculations led to red uctions of less than $10 \%$ in the es timated rates of protein synthesis.

Analysis of the excretion of ammonia- ${ }^{15} \mathrm{~N}$ in the urine yielded different results for size and turnover rate of the metabolic pool and the rate of protein synthesis in each infant. These differences serve to emphasize the oversimplification inherent in the San Pietro-Rittenberg treatment.

From the estimated protein content of weight gained by these infants, and their respective rates of protein synthesis, it could be calculated that they retained $12.2,14.9$, and $6.8 \%$ of the total protein synthesized.

The adherence of the data obtained in these studies to that predicted by the SAN PIETRO-RIT TENBERG equation was that which would be expected if the protein synthesized during the course of the study had a relatively long half-life.

Comparison of the results of these studies with similar studies performed in adults leads to the conclusion that a large pool of metabolic nitrogen and a slow turnover of that pool are common to states of protein accumulation.
\end{abstract}

\section{Speculation}

These studies suggest that rates of protein synthesis in premature infants are comparable to rates of protein synthesis in adults (on the basis of surface area), and that premature infants, in contrast to adults, achieve rapid growth by the synthesis of proteins with longer biological half-lives.

\section{Introduction}

In 1953, SAN Pietro and Rittenberg estimated the overall rate of protein synthesis in the human adult male [14]. Their method is based on a simplified model of nitrogen metabolism and employs a mathematical analysis of the rate and mode of the excretion of ${ }^{15} \mathrm{~N}$ following administration of $\mathrm{a}^{15} \mathrm{~N}$-labeled amino acid to the subject. While the studies of SAn Pretro and RITTENBERG involved normal adults in nitrogen balance, 
the method was subsequently employed by others for serial studies of diseased subjects under various metabolic conditions $[2,5,9,18]$. The mathematical model has been criticized as an oversimplification $[10,22]$ but has been found to give consistent results in the presence of dietary variations and to demonstrate consistent responses to therapy in patients with three different endocrinopathies $[2,5]$.

The present study extends the use of the SAN PietroRITTENBERG method to isolated estimates of the rate of protein synthesis in rapidly growing premature infants. The following review deals principally with the general applicability of the method and with the metabolic requirements for its use as defined by SAN PIETro and RitTEnbERG.

Figure 1 illustrates the San Pietro-Rittenberg model of nitrogen metabolism. The central feature is a homogeneous pool of metabolically active nitrogen which is defined by function, i.e., it is the direct source of nitrogen for the synthesis of tissue constituents and for the formation of excretory nitrogenous compounds. It is approximately equal in magnitude to the total nitrogen of the free $\alpha$-amino acids of the body. The rate of nitrogen metabolism is, by definition, the product of the size of this metabolic pool $(\mathrm{P})$ and its turnover rate (B) :

$$
\text { rate of nitrogen metabolism }=\mathrm{P} \times \mathrm{B}
$$

The fates of metabolically active nitrogen are restricted, from a quantitative standpoint, to two: 1) incorporation into protein, and 2) excretion.

If the size of the metabolic pool and the size of the pool of excretory nitrogen remain constant, the sum of the rate of protein synthesis $(\mathrm{S})$ and the rate of nitrogen excretion $\left(E_{t}\right)$ is equal to the rate of nitrogen metabolism:

$$
\text { rate of nitrogen metabolism }=\mathrm{S}+\mathrm{E}_{\mathrm{t}}
$$

From equations 1 and 2 it follows that:

$$
\begin{gathered}
\mathrm{S}+\mathrm{E}_{\mathrm{t}}=\mathrm{P} \times \mathrm{B}, \text { and } \\
\mathrm{S}=\mathrm{P} \times \mathrm{B}-\mathrm{E}_{\mathrm{t}}
\end{gathered}
$$

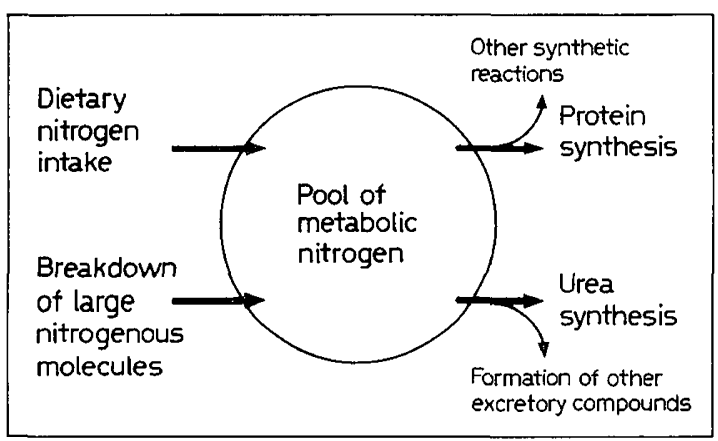

Fig. 1.The pool of metabolic nitrogen and its relation to the processes of nitrogen metabolism as conceived by San Pietro and Rittenberg [14].
For the sake of conceptual simplicity, one can assume that subjects are in nitrogen balance. It is clear, however, that the method requires only that the metabolic pool and the excretory pool of nitrogen be the same at the beginning and end of any given period of evaluation. Since these two quantities are to some extent functions of body size, they will vary somewhat with changes in body size. Undoubtedly, they are notsignificantly different at the beginning and end of any given 24-h period in an individual who is in a metabolic steady-state.

For the determination of $\mathrm{S}$, it is necessary to measure $\mathrm{B}, \mathrm{P}$, and $\mathrm{E}_{\mathrm{t}}$. The $\mathrm{E}_{\mathrm{t}}$ can be measured directly. For the measurement of $B$ and $P$, the concept of a dynamic state of the metabolic pool of nitrogen in considering the metabolism of a single amino acid labeled with ${ }^{15} \mathrm{~N}$ is used. When a suitable amino acid is introduced into the metabolic pool, the nitrogen of the amino acid is rapidly incorporated into other amino acids by transamination and other reactions [13]. For purposes of mathematical treatment, one can make the simplifying assumption that a single reactive amino acid, labeled with ${ }^{15} \mathrm{~N}$ and administered to a subject, labels the pool of metabolic nitrogen of the subject instantly and uniformly. The rate of disappearance of the isotope from the metabolic pool then directly reflects the rate of turnover of the metabolic pool. To determine the rate of disappearance of the label from the metabolic pool, it is necessary to evaluate the synthesis and excretion of urea- ${ }^{15} \mathrm{~N}$, assuming urea formation to be a function of general nitrogen metabolism and to reflect properly the fate of the metabolic pool as a whole. The following equations outline the essential features of the method:

From general considerations the amount of ${ }^{15} \mathrm{~N}$ remaining in the metabolic pool, $(\lambda p)$ at any time $(t)$ may be expressed as follows:

$$
\lambda \mathrm{p}=\lambda_{\mathrm{o}} \mathrm{e}^{-\mathrm{B} t}
$$

where $\lambda_{0}$ is the amount of ${ }^{15} \mathrm{~N}$ administered.

Under steady-state conditions, the overall synthesis of urea (Es) is equal to the overall excretion of urea (Eu). Since the rate of disappearance of urea- ${ }^{15} \mathrm{~N}(\lambda \mathrm{u})$ from the total pool of urea (U) is a function of both the rate of excretion of urea and of the synthesis of urea from amino $\operatorname{acid}-{ }^{15} \mathrm{~N}(\lambda \mathrm{p})$ in the metabolic pool $(\mathrm{P})$, the following equation obtains:

$$
-\frac{\mathrm{d} \lambda \mathrm{u}}{\mathrm{d}_{t}}=\frac{\lambda \mathrm{u}}{\mathrm{U}} \mathrm{Eu}-\frac{\lambda \mathrm{p}}{\mathrm{P}} \mathrm{Eu}
$$

From equations 5 and 6 it follows that:

$$
-\frac{\mathrm{d} \lambda \mathrm{u}}{\mathrm{d}_{t}}=\frac{\lambda \mathrm{u}}{\mathrm{U}} \mathrm{Eu}-\frac{\lambda_{\mathrm{o}} \mathrm{e}^{-\mathrm{B} t}}{\mathrm{P}} \mathrm{Eu}
$$

Equation 7 was solved by SAN Pietro and Rrttenberg, and evaluated at maximum urea- ${ }^{15} \mathrm{~N}$ concentration to 
yeld $B$ and $P$. The method requires that total body urea remain constant, and that urea synthesis be a reflection of general nitrogen metabolism.

With $\mathrm{B}$ and $\mathrm{P}$ determined indirectly and $\mathrm{E}_{\mathrm{t}}$ determined directly, it is possible to determine the overall rate of protein synthesis through the use of equation 4.

In general, it is evident that the postulation of a single metabolic pool of nitrogen, homogeneous throughout the body, is an oversimplification, as is the concept of unified, homogeneous processes of nitrogen excretion and protein synthesis. For the mathematical method employed, it is necessary only that the experimental data derived from several pools reacting in several ways at several rates behave according to the postulated scheme--that the sum of metabolic pools behave as if there were one pool, and the sum of rates of protein synthesis and the sum of rates of nitrogen excretion behave as if they were single continuous functions.

In the present study, premature infants were evaluated by this technique to: 1) obtain first approximations of the premature infant's rate of protein synthesis in the presence of rapid growth, and 2) determine how the premature infant differs from the adult with respect to the size and rate of turnover of the pool of metabolic nitrogen.

\section{Materials and Methods}

\section{Subjects}

Three premature male infants were studied during a period of good health and rapid growth [26]. Table I shows ages and weights at the time of study, and table VIII shows rates of weight gain. Male infants were chosen to assure quantitative urine collections and complete separation of urine and feces.

\section{Experimental}

Glycine- ${ }^{15} \mathrm{~N}, 97$ atoms $\%{ }^{15} \mathrm{~N}$ [23], was administered orally in conjunction with a normal formula feeding [24] immediately after the infant had voided spontaneously. Subsequent spontaneously voided urine specimens were collected quantitatively and frozen in dry ice. Stool specimens were collected separately. Normal feedings and procedures of infant care were carried out throughout the studies.

\section{Analytical}

Urine specimens were diluted to standard volumes. Aliquots were taken for the determination in duplicate of total nitrogen and ${ }^{15} \mathrm{~N}$, urea nitrogen and ${ }^{15} \mathrm{~N}$, and ammonia nitrogen and ${ }^{15} \mathrm{~N}$. Total nitrogen was determined by the Kjeldahl method as modified by SPRINSON and RitTENBERG [17]. Urea was determined by incubation of permutit-treated urine with urease, followed by Conway diffusion and titration [6]. Ammonia was determinated by isolation on permutit, followed by titration [7]. Duplicate samples of ammonium sulfate from the above determinations were combined and reacted with sodium hypobromite [17]. The resulting nitrogen was analyzed in a mass spectrometer having a precision of not less than 5 parts $/ 100,000$. In some cases, when the amount of ammonium ion determined by titration was insufficient for mass spectrometric analysis $(<0.25 \mathrm{mg}$ $\mathrm{N})$, unlabeled ammonium hydroxide was added to the titration vessel and the sample titrated to a new end point. The ${ }^{15} \mathrm{~N}$ was determined as described above. For all samples, the actual isotope concentration was obtained by use of the following equation:

actual atoms $\%$ excess $=$

observed atoms \% excess $\times$ total $\mathrm{mEq} \mathrm{N}$ total $\mathrm{mEq} \mathrm{N}$ - blank $\mathrm{mEq} \mathrm{N}$ - carrier mEq N

Table I. Evaluation of nitrogen metabolism in premature infants by the method of SAN PiETro and RITTENBERG

\begin{tabular}{lccccccccccc}
\hline Infant & $\begin{array}{c}\text { Age at } \\
\text { study, } \\
\text { days }\end{array}$ & $\begin{array}{c}\mathrm{Wt}, \\
\mathrm{g}\end{array}$ & $\begin{array}{c}\lambda_{\mathrm{o},{ }^{1}} \mathrm{mEq} \\
{ }^{15 \mathrm{~N}}\end{array}$ & $\mathrm{U}^{2}$ & $\begin{array}{c}\mathrm{Eu}^{3} \\
\mathrm{mEq}\end{array}$ & $\mathrm{E}_{\mathrm{t}}{ }^{4}$ & $\begin{array}{c}t \\
\max ,{ }^{5} \\
\text { days }\end{array}$ & $\begin{array}{c}\mathrm{C} \\
\mathrm{max},{ }^{6} \\
\mathrm{~A} \%\end{array}$ & $\begin{array}{c}\mathrm{B},{ }^{7} \\
1 / 24 \mathrm{~h}\end{array}$ & $\begin{array}{c}\mathrm{P},{ }^{8} \\
\mathrm{~g} \mathrm{~N}\end{array}$ & $\begin{array}{c}\mathrm{S},{ }^{9} \\
\mathrm{~g} \mathrm{~N} / \\
24 \mathrm{~h}\end{array}$ \\
\hline$F B$ & 42 & 2,200 & 0.643 & 15.8 & 26.34 & 39.4 & 0.164 & 0.240 & 15.1 & 0.315 & 4.203 \\
$M c C$ & 29 & 2,310 & 0.643 & 22.4 & 34.45 & 45.7 & 0.183 & 0.229 & 13.5 & 0.338 & 3.909 \\
$D C$ & 68 & 2,380 & 0.626 & 24.8 & 47.28 & 63.2 & 0.181 & 0.174 & 12.1 & 0.560 & 5.898 \\
\hline
\end{tabular}

${ }^{1} \lambda \mathrm{o}$, dose of amino acid- ${ }^{15} \mathrm{~N}$ administered.

$2 \mathrm{U}$, urea pool.

${ }^{3} \mathrm{Eu}$, urea excreted per day.

${ }^{4} \mathrm{E}_{t}$, nitrogen excreted per day.

${ }_{\mathrm{t}}$ max, time of maximum [urea-15N].
${ }^{6} \mathrm{C}$ max, maximum [urea- $\left.{ }^{15} \mathrm{~N}\right]$.

' $\mathrm{B}$, turnover rate for metabolic pool of nitrogen.

${ }^{8} \mathrm{P}$, metabolic pool of nitrogen.

${ }^{9} \mathrm{~S}$, rate of protein synthesis. 
Stool specimens were homogenized and diluted to standard volumes. Duplicate aliquots were analyzed for total nitrogen and ${ }^{15} \mathrm{~N}$ as described above.

Total body urea (U) was estimated by the product of plasma urea nitrogen and total body water:

urea concentration $\times$ total body water $=$ total body in plasma water $\times$ total bodywater $=$ urea

The calculations of total body urea employ values for total body water for premature infants according to weight and age, as determined by Clapp et al. [1].

\section{Results}

The analytical variables used and the results obtained in these studies are shown in table I. The values obtained in the analyses of urine specimens are shown in table II and the results of the analyses of fecal specimens in the three studies appear in table III. Calculations were carried out using milliequivalents $(\mathrm{mEq})$ as the unit of measurement for nitrogen since the molecular weight of nitrogen varies with its ${ }^{15} \mathrm{~N}$ content. The tabulated values for $\mathrm{P}$ and $\mathrm{S}$ were obtained by multiplying the corresponding values in milliequivalents by the factor $0.01401 \mathrm{~g} / \mathrm{mEq}$. As shown in table $\mathrm{I}$, analysis by the method of SAN Pietro and Rittenberg indicated that the infants had pools of metabolically active nitrogen of $0.143,0.146$, and $0.236 \mathrm{~g} \mathrm{~N} / \mathrm{kg}$, respectively, with turnover rates of 15.1, 13.5, and 12.1/ $24 \mathrm{~h}$. The rates of protein synthesis were 1.9, 1.7, and $2.5 \mathrm{~g} \mathrm{~N} / \mathrm{kg} / 24 \mathrm{~h}$.

\section{Discussion}

Choice of ${ }^{15} \mathcal{N}$-Amino Acid and Mode of Administration

Glycine-15 $\mathrm{N}$ was chosen for these studies because it has been the amino acid most often used in the past and, therefore, provides a basis for comparison of studies of this type. As the simplest amino acid, and the only optically inactive one, glycine has been extensively studied and has been found to participate in a number of reactions involving neither nitrogen excretion nor protein synthesis. This diversity of pathways may limit the usefulness of glycine for studies of the type presented here.

Oral administration was chosen because it provided a physiologic entry for the amino acid. Moreover, $\mathrm{Wu}$ et al. [22] found that oral administration of an

Table II. Excretion of nitrogen and ${ }^{15} \mathrm{~N}$ following ingestion of glycine- ${ }^{15} \mathrm{~N}^{1}$

\begin{tabular}{|c|c|c|c|c|c|}
\hline \multirow{2}{*}{$\begin{array}{l}\text { Sam- } \\
\text { ple } \\
\text { no. }\end{array}$} & \multirow{2}{*}{$\begin{array}{l}\text { Time } \\
\text { col- } \\
\text { lected, } \\
\text { days }\end{array}$} & \multicolumn{4}{|c|}{ Analyses of urine } \\
\hline & & $\begin{array}{l}\text { Am- } \\
\text { monia } \\
\text { A\%, }\end{array}$ & $\begin{array}{l}\text { Urea } \\
\text { excess }\end{array}$ & $\begin{array}{l}\text { Urea } \\
\qquad \mathrm{N}\end{array}$ & $\begin{array}{c}\text { Total } \\
\mathrm{N}\end{array}$ \\
\hline 1 & 0.033 & 0.648 & 0.025 & 1.151 & 1.440 \\
\hline 2 & 0.041 & $(0.925)^{2}$ & 0.079 & 0.757 & 0.966 \\
\hline 3 & 0.053 & 0.914 & 0.133 & 0.619 & 0.793 \\
\hline 4 & 0.063 & 0.861 & 0.155 & 0.622 & 0.789 \\
\hline 5 & 0.071 & 0.763 & 0.163 & 0.285 & 0.369 \\
\hline 6 & 0.075 & 0.695 & 0.173 & 0.450 & 0.548 \\
\hline 7 & 0.085 & 0.598 & 0.189 & 0.537 & 0.685 \\
\hline 8 & 0.094 & 0.608 & 0.199 & 0.588 & 0.728 \\
\hline 9 & 0.167 & 0.472 & 0.221 & 2.247 & 2.996 \\
\hline 10 & 0.211 & 0.269 & 0.229 & 1.813 & 2.347 \\
\hline 11 & 0.248 & 0.184 & 0.211 & 1.646 & 2.161 \\
\hline 12 & 0.267 & 0.207 & 0.222 & 0.974 & 1.234 \\
\hline 13 & 0.403 & 0.101 & 0.177 & 1.859 & 2.390 \\
\hline 14 & 0.517 & 0.081 & 0.148 & 3.943 & 5.016 \\
\hline 15 & 0.618 & 0.070 & 0.126 & 5.077 & 6.432 \\
\hline 16 & 0.865 & 0.058 & 0.100 & 11.673 & 14.648 \\
\hline 17 & 1.007 & 0.041 & 0.071 & 0.214 & 2.460 \\
\hline 18 & 1.257 & 0.037 & 0.063 & 3.023 & 3.793 \\
\hline 19 & 1.507 & 0.032 & 0.043 & 9.637 & 11.311 \\
\hline 20 & 1.757 & 0.020 & $(0.033)^{2}$ & 12.042 & 14.682 \\
\hline 21 & 1.888 & 0.023 & 0.029 & 11.082 & 13.893 \\
\hline
\end{tabular}

${ }^{1}$ Subject $M c C$, dose : $0.643 \mathrm{mEq}{ }^{15} \mathrm{~N}$.

${ }^{2}$ Value obtained from the curve $\left[\mathrm{NH}_{3}{ }^{15} \mathrm{~N}\right]$ versus time.

Table III. Fecal nitrogen and ${ }^{15} \mathrm{~N}$ following ingestion of glycine- ${ }^{15} \mathrm{~N}$ by premature infants

\begin{tabular}{|c|c|c|c|c|c|c|}
\hline Infant & $\begin{array}{l}\text { Collection } \\
\text { interval, } \\
\text { days }\end{array}$ & $\begin{array}{l}\text { Fecal N, } \\
\text { mEq }\end{array}$ & $\begin{array}{l}\frac{\text { Fecal } N}{\text { Fecal } N+} \times 100 \\
\text { urinary } N\end{array}$ & $\begin{array}{l}\text { Fecal }{ }^{15} \mathrm{~N} \\
\mathrm{mEq}\end{array}$ & $\begin{array}{l}\frac{\text { Fecal }}{\text { Fecal }^{15}{ }^{15} \mathrm{~N}+} \\
\text { urinary }{ }^{15} \mathrm{~N}\end{array}$ & $\frac{\text { Fecal }{ }^{15} \mathrm{~N}}{{ }^{15 \mathrm{~N}} \text { administered }}$ \\
\hline \multirow[t]{2}{*}{$F B$} & $0-1.014$ & 15.146 & 28.4 & 0.005086 & 6.9 & 0.8 \\
\hline & $0-2.014$ & 30.469 & 29.9 & 0.008424 & 9.2 & 1.3 \\
\hline \multirow[t]{2}{*}{$M c C$} & $0-0.978$ & 24.388 & 34.7 & 0.008423 & 10.9 & 1.3 \\
\hline & $0-2.007$ & 43.082 & 32.4 & 0.013364 & 13.7 & 2.1 \\
\hline \multirow[t]{2}{*}{$D C$} & $0-1.031$ & 20.137 & 24.1 & 0.006982 & 9.0 & 1.1 \\
\hline & $0-1.659$ & 33.998 & 26.3 & 0.010004 & 10.7 & 1.6 \\
\hline
\end{tabular}


amino acid labeled with ${ }^{15} \mathrm{~N}$ resulted in an excretory pattern more compatible with a single pool of metabolic nitrogen than does intravenous administration. Oral administration introduced some uncertainty with regard to time of absorption; however, in the present studies, it was decided to accept as $t_{0}$ for each study the time of voiding of the last urine specimen not containing urea- ${ }^{15} \mathrm{~N}$. The $t_{0}$ measured by this means was identical with the time of last voiding before the administration of glycine- ${ }^{15} \mathrm{~N}$ in two subjects and was 0.023 days after the administration of glycine- ${ }^{15} \mathrm{~N}$ in the third subject $(D C)$.

\section{Analyses of Feces}

SAN Pietro and Rittenberg considered fecal nitrogen to be quantitatively insignificant for studies of adult subjects by their method.

Such an assumption cannot be made for premature infants because fecal nitrogen may account for more than $30 \%$ of the total nitrogen excreted by the infant [4]. As shown in table III, fecal nitrogen accounted for $25-35 \%$ of the total nitrogen excreted by the infants in this study. Fecal ${ }^{15} \mathrm{~N}$, however, accounted for only $7-14 \%$ of the total ${ }^{15} \mathrm{~N}$ excreted. The total amount of ${ }^{15} \mathrm{~N}$ excreted in feces by the infants represented less than $1.5 \%$ of the dose administered during the first $24 \mathrm{~h}$, and less than $2.5 \%$ of the dose during the first $48 \mathrm{~h}$, after administration of the isotope.

It is difficult to assess the metabolic significance of fecal nitrogen. For present purposes it would seem best to consider fecal nitrogen in terms of its ${ }^{15} \mathrm{~N}$ content, since the primary concern of this investigation is the fate of a pool of metabolic nitrogen labeled with ${ }^{15} \mathrm{~N}$. Unfortunately, the uncertainties regarding the origin of fecal nitrogen hamper such an attempt.

In terms of the calculated rate of protein synthesis, the largest correction for fecal nitrogen that could be made was that which followed when all fecal nitrogen was considered to be part of $E_{t}$. As shown in table IV, the decrements in protein synthesis achieved by this correction were less than $10 \%$. Since fecal nitrogen in these studies had a much lower overall ${ }^{15} \mathrm{~N}$ concentration than contemporaneously excreted nitrogen in urine, it was likely that the amount of metabolically active nitrogen excreted in feces was less than the total nitrogen of feces. When fecal nitrogen was considered in terms of its ${ }^{15} \mathrm{~N}$ content, the decrements in $\mathrm{S}$ were considerably less than $10 \%$.

\section{Analyses of Urine}

As anticipated from the results of others [15], the infants excreted relatively large amounts of urinary ammonia and relatively small (69-78\% of total nitrogen) amounts of urea when compared with normal adult subjects.
Evaluation of ammonia- ${ }^{15} \mathcal{N}$ in urine. Since ammonia found in urine is derived directly from the metabolic pool of nitrogen, measurement of the ${ }^{15} \mathrm{~N}$ concentration of ammonia in urine should afford a direct measure of the concentration of ${ }^{15} \mathrm{~N}$ in the metabolic pool. In this case, a precursor-product relation should exist between the ${ }^{15} \mathrm{~N}$ concentration of ammonia and the ${ }^{15} \mathrm{~N}$ concentration of urea in urine; i.e., the concentration of ${ }^{15} \mathrm{~N}$ in ammonia and urea should be equal at the point of maximum ${ }^{15} \mathrm{~N}$ concentration in urea. Table $\mathrm{V}$ shows that this condition was nearly, but not exactly, fulfilled. If the concentration of ${ }^{15} \mathrm{~N}$ in ammonia was a direct reflection of the ${ }^{15} \mathrm{~N}$ concentration in the metabolic pool as a whole, it would also be expected that $B$ and $P$ could be determined by analysis of the disappearance of isotope from ammonia in urine. With this assumption, equation 5 may be rewritten.

Table $\mathrm{V}$. Values for the rates of protein synthesis in premature infants, obtained when fecal nitrogen is assumed to be included in $\mathrm{E}_{\mathrm{t}} \mathrm{S}=\mathrm{BP}-\mathrm{E}_{\mathrm{t}}$.

\begin{tabular}{lccc}
\hline Infant & $\begin{array}{c}\mathrm{S}, \\
\mathrm{gN} / 24 \mathrm{~h} \\
\mathrm{E}_{\mathrm{t}}=\text { urinary } \mathrm{N}\end{array}$ & $\begin{array}{c}\mathrm{S}, \\
\mathrm{g} \mathrm{N} / 24 \mathrm{~h} \\
=\text { urinary } \mathrm{N} \\
+ \text { fecal N }\end{array}$ & $\begin{array}{c}\text { Change, } \\
\%\end{array}$ \\
\hline$F B$ & 4.203 & 3.993 & 5 \\
$M c C$ & 3.909 & 3.629 & 7 \\
$D C$ & 5.898 & 5.618 & 5 \\
\hline
\end{tabular}

Table V. Precursor-product relation between [ammonia- $\left.{ }^{15} \mathrm{~N}\right]$ and [urea-1;N] in urine of premature infants following ingestion of glycine- ${ }^{15} \mathrm{~N}$

\begin{tabular}{lccc}
\hline Infant & $\begin{array}{r}\text { Maximum } \\
{\left[\mathrm{NH}_{3}{ }^{15} \mathrm{~N}\right]} \\
\text { in urine }\end{array}$ & $\begin{array}{r}\text { Maximum } \\
{\left[\text { urea- }{ }^{-15} \mathrm{~N}\right]} \\
\text { in urine } \\
\mathrm{A} \% \text { excess }\end{array}$ & $\begin{array}{c}\text { Urinary }\left[\mathrm{NH}_{3}-{ }^{15} \mathrm{~N}\right] \\
\text { at } t \text { max for } \\
{\left[\text { urea- }{ }^{-15} \mathrm{~N}\right]}\end{array}$ \\
\hline$F B$ & 0.972 & 0.240 & 0.315 \\
$M C C$ & 0.914 & 0.229 & 0.269 \\
$D C$ & 0.446 & 0.174 & 0.182 \\
\hline
\end{tabular}

Table VI. The $\mathrm{B}, \mathrm{P}$, and $\mathrm{S}$ as determined by graphic analysis of $\left[{ }^{15} \mathrm{~N}\right]$ in urinary ammonia of premature infants following ingestion of glycine- ${ }^{15} \mathrm{~N}$

\begin{tabular}{lccc}
\hline Infant & $\mathrm{B}, \mathrm{I} / 24 \mathrm{~h}$ & $\mathrm{P}, \mathrm{g} \mathrm{N}$ & $\mathrm{S}, \mathrm{g} \mathrm{N} / 24 \mathrm{~h}$ \\
\hline$F B$ & 8.4 & 0.647 & 4.889 \\
$M c C$ & 8.3 & 0.689 & 5.086 \\
$D C$ & 7.2 & 1.098 & 7.019 \\
\hline
\end{tabular}


$\left[{ }^{15} \mathrm{~N}-\mathrm{NH}_{3}\right]=\left[{ }^{15} \mathrm{~N}-\mathrm{NH}_{3}\right]$ o e ${ }^{-\mathrm{B} t}$

(10)

When $\log _{\mathrm{e}}\left[{ }^{15} \mathrm{~N}-\mathrm{NH}_{3}\right]$ is plotted against time, the slope of the line obtained is $\mathrm{B}$, and the intercept at $t=0$ allows the determination of $\mathrm{P}$ by the principle of isotope dilution. Although the observed values for $\left[{ }^{15} \mathrm{~N}-\mathrm{NH}_{3}\right]$ give a linear semilogarithmic plot against time for only a short interval following the peak $\left[{ }^{15} \mathrm{~N}-\mathrm{NH}_{3}\right]$, initial slopes may be obtained, and intercepts determined, with considerable reliability. The results of these analyses are presented in table VI. It can be seen that values for $\mathrm{P}$ are larger, and values for $\mathrm{B}$, smaller, than those obtained by the San Pietro-Rittenberg technique. The most likely explanation for this finding is that the metabolic pool of nitrogen that yielded ammonia in urine was not fully labeled instantaneously. Therefore, the initial ${ }^{15} \mathrm{~N}$ concentration was lower than would be expected under conditions of instantaneous labeling. Continued transfer of ${ }^{15} \mathrm{~N}$ into the ammonia-yielding pool maintained the ${ }^{15} \mathrm{~N}$ concentration in that pool at a relatively high level, thus reducing the apparent turnover rate of the pool.

The results obtained by VAN SLYKE and associates [19], and more recently by Prxxs et al. [12], clearly indicate that ammonia formation is a more specialized function of nitrogen metabolism than is urea formation. Therefore, the method of SAN Pietro and RittenberG would appear to be more physiologically appropriate for studies of overall nitrogen metabolism than would the analysis of ammonia formation. The difference in results between these two approaches, however, illustrates the most serious defect in the SAN PIETRo-RittenBERG model : the assumption that an amino acid labeled with ${ }^{15} \mathrm{~N}$ instantaneously and uniformly labels the metabolic pool of nitrogen when introduced into the pool. Wu and Bishop [21] have shown that the ${ }^{15} \mathrm{~N}$ of glycine- ${ }^{15} \mathrm{~N}$ is by no means instantaneously dispersed. Rittenberg [13] demonstrated that the distribution of ${ }^{15} \mathrm{~N}$ from glycine ${ }^{15} \mathrm{~N}$ in plasma proteins is by no means uniform with respect to the amino acid residues isolated from the proteins. The validity of the results obtained by the use of the SAN PIETRo-Rittenberg model is then clearly dependent to some extent on the degree to which the metabolism of the nitrogen of the amino acid administered reflects the metabolism of the metabolic pool of nitrogen as a whole. Recently, Picou and TAYlOR-Roberts [11] have published evidence bearing on this point. Using a different experimental approach, they compared the metabolism of glycine- ${ }^{15} \mathrm{~N}$ and egg protein- ${ }^{15} \mathrm{~N}$ in older infants. Their analyses of the data obtained with these two substances yielded very similar values for rates of protein synthesis and turnover.

Theoretical and actual excretion of urea- ${ }^{15} \mathcal{N}$. Using the values determined for $B$ and $P$, equation 7 can be in- tegrated [14] to yield values for the cumulative excretion of urea- ${ }^{15} \mathrm{~N}$. As shown in table VII, the values for calculated and observed urea- ${ }^{15} \mathrm{~N}$ were quite dissimilar in studies of adult subjects. As an explanation for this discrepancy, San Pietro and Rittenberg reasoned that a certain amount of metabolically active nitrogen labeled with ${ }^{15} \mathrm{~N}$ was returned to the metabolic pool from the breakdown of protein synthesized during the course of the study. The values for calculated and observed urea- ${ }^{15} \mathrm{~N}$ excretion in the premature infants are much more nearly equal and do not permit the use of the constant term for reentry of ${ }^{15} \mathrm{~N}$ into the metabolic pool devised by San Pietro and Rittenberg. There are several possible explanations for this finding. It is possible that the observed urea- ${ }^{15} \mathrm{~N}$ excretion is lowered by diversion of urea- ${ }^{15} \mathrm{~N}$ into fecal ${ }^{15} \mathrm{~N}$. The figures in parentheses in table VII present values for urea- ${ }^{15} \mathrm{~N}$ observed/urea- ${ }^{15} \mathrm{~N}$ calculated $\times 100$, obtained when all fecal ${ }^{15} \mathrm{~N}$ is considered to be part of urea- ${ }^{15} \mathrm{~N}$. It can be seen that such a correction would account for some, but not all, of the discrepancy between the values obtained for premature infants and those obtained for adult subjects. It is also possible that urea- ${ }^{15} \mathrm{~N}$ synthesized by the infant is broken down in the gastrointestinal tract to yield ammonia- ${ }^{15} \mathrm{~N}$, which is then returned to the metabolic pool and used for protein synthesis, thus reducing the urinary excretion of urea- ${ }^{15} \mathrm{~N}$. It has been shown that the oral administration of urea- ${ }^{15} \mathrm{~N}$ to infants receiving a diet restricted in nitrogen content leads to significant incorporation of ${ }^{15} \mathrm{~N}$ into plasma proteins [16].

Table VII. Cumulative excretion of urea- ${ }^{15} \mathrm{~N}$ by adults and premature infants following ingestion of amino acid- ${ }^{15} \mathrm{~N}$

\begin{tabular}{lccc}
\hline Subjects & \multicolumn{2}{c}{$\frac{\lambda \mathrm{e}}{\lambda_{\mathrm{o}}} \times 100^{1} \frac{\lambda \mathrm{e}}{\lambda_{\mathrm{o}}} \times 100^{1} \frac{\text { Calculated }}{\text { Observed }} \times 100$} \\
& calculated observed \\
\hline Adults [14] & & & \\
$D R$ (glycine) & 17.0 & 24.9 & 146 \\
$A S$ (glycine) & 9.84 & 23.0 & 234 \\
$A S$ (aspartic & 23.8 & 41.5 & 174 \\
$\quad$ acid) & & & \\
Premature & & & \\
infants & & & \\
$F B$ & 7.48 & 7.54 & $101(118)^{2}$ \\
$M c C$ & 9.87 & 9.55 & $97(118)^{2}$ \\
$D C$ & 11.30 & 10.56 & $94(108)^{2}$ \\
\hline
\end{tabular}

${ }^{1} \frac{\lambda \mathrm{e}}{\lambda_{\mathrm{o}}} \times 100=$ percentage of administered dose excreted.

${ }^{2}$ Figures in parentheses are values for observed/calculated $\times 100$ when total fecal ${ }^{15} \mathrm{~N}$ is included as part of the observed urea- ${ }^{15} \mathrm{~N}$ excreted. 
In normal adults [20], the ammonia produced by bacterial decomposition of urea- ${ }^{15} \mathrm{~N}$ in the gastrointestinal tract is, in considerable part, used for the formation of new urea- ${ }^{15} \mathrm{~N}$. In the present instance, the discrepancy between adult and infant would be explained if $50 \%$ or more of the ${ }^{15} \mathrm{~N}$ incorporated into urea by the infant was liberated as ammonia in the gastrointestinal tract and subsequently incorporated into nitrogenous compounds other than urea. A third, and most obvious explanation for the close correlation between observed and calculated urea- ${ }^{15} \mathrm{~N}$ excretion in the infants is that there is little return of ${ }^{15} \mathrm{~N}$ from protein to the metabolic pool during the course of the studies. This would imply that the protein synthesized by the infants has a longer half-life than that synthesized by normal adults, a reasonable implication since the infant is accumulating structural protein at an appreciable rate.

Rate of growth and the rate of protein synthesis. The rate of accumulation of protein by the growing infant may be approximated by the product of the fractional protein content of infants and the rate of weight gain by the infants. Such an estimate was made for the infants in this study, using values for nitrogen and protein as percentage of body weight for infants of similar weight $[3,8]$. The values for estimated daily gain in protein were compared with rates of protein synthesis as determined by the SAN Pietro-Rittenberg technique (table VIII). It can be seen that the rate of protein synthesis far exceeds the rate of protein accumulation and that 'growth protein' accounts for approximately $10 \%$ of the total protein synthesized each day.

Comparison of $B, P$, and $S$ in premature infants with values from studies in adult subjects. Figure 2 shows a comparison of values for $\mathrm{B}, \mathrm{P}$, and $\mathrm{S}$ as determined in premature infants and in adults in various metabolic states [5, 14]. Since $B$ has as its unit of measurement, $1 / 24 \mathrm{~h}$, a direct comparison of turnover rates was possible. For $\mathrm{P}$ and $\mathrm{S}$ the observed values were plotted as grams nitrogen per kilogram of body weight 0.7 to minimize variation as a function of body size. With respect to the normal adult in nitrogen balance, the growing premature infant has a large pool of metabolic nitrogen which turns over at a slow rate. Rates of protein synthesis are roughly equal.

Table VIII. Efficiency of protein synthesis in the premature infant

\begin{tabular}{|c|c|c|c|c|}
\hline Infant & $\begin{array}{l}\text { Mean wt } \\
\text { gain, } \\
\text { g/24h }\end{array}$ & $\begin{array}{c}\text { Protein } \\
\text { gain, } \\
0.11 \times \\
\text { mean wt ga }\end{array}$ & $\begin{array}{l}\mathrm{S}, \\
\text { g protein/ } \\
24 \mathrm{~h} \\
\end{array}$ & 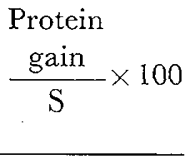 \\
\hline$F B$ & 29 & 3.2 & 26.3 & 12.2 \\
\hline$M c C$ & 33 & 3.6 & 24.4 & 14.8 \\
\hline$D C$ & 23 & 2.5 & 36.9 & 6.8 \\
\hline
\end{tabular}

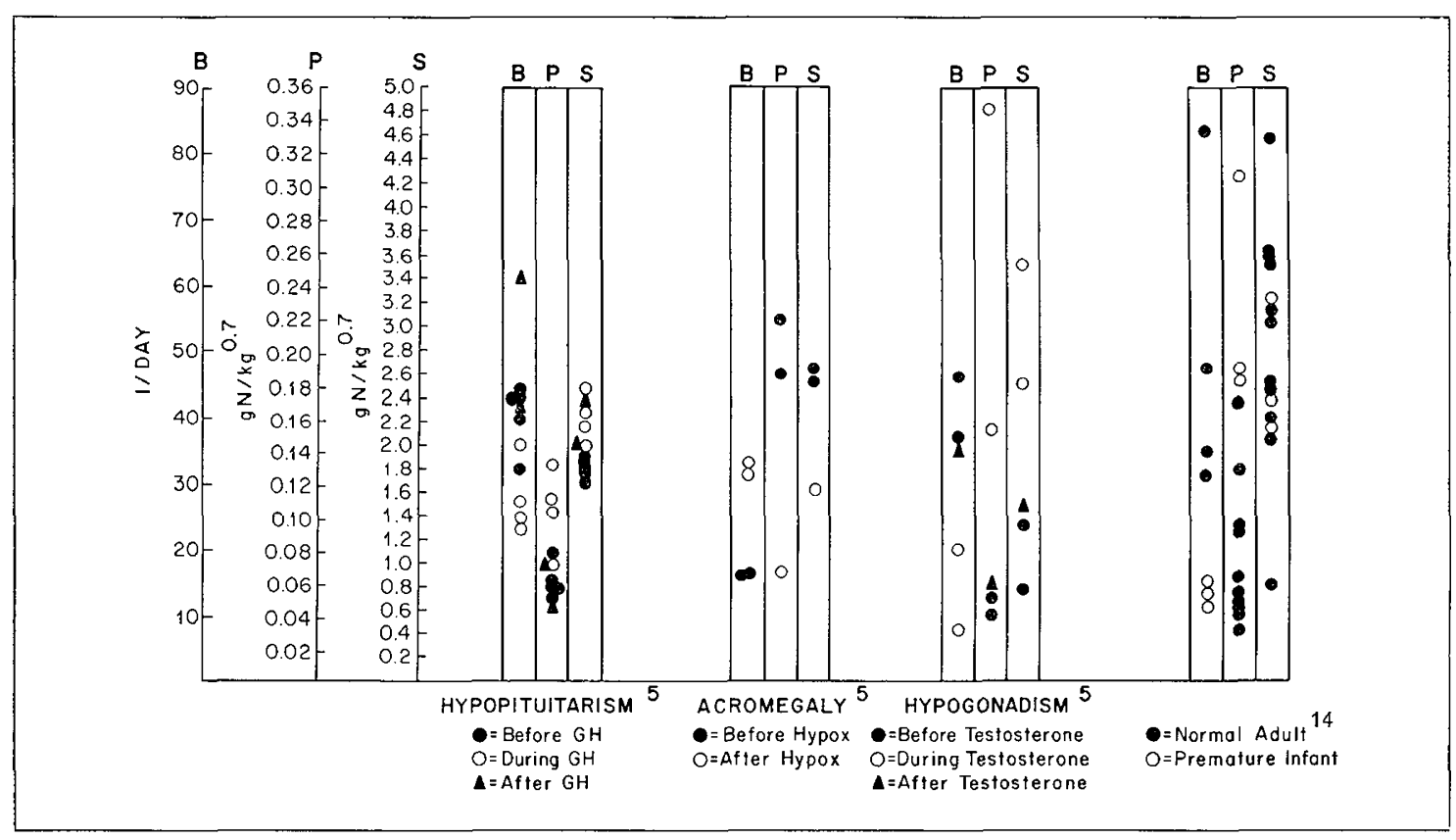

Fig. 2. Size and turnover rate of the pool of metabolic nitrogen and rate of protein synthesis as determined in adults by San Pretro and Rittenberg [14], and HaAk [5], and in premature infants of this study. 
It can also be seen that growth hormone therapy in hypopituitarism, excessive growth hormone in acromegaly, and testosterone therapy in hypogonadism all lead to increased size of the metabolic pool, decreased turnover rate, and increased rate of protein synthesis. It would seem reasonable to conclude that a large pool of metabolically active nitrogen and a slow turnover rate are common to states of protein accumulation.

\section{Summary}

The size of the metabolic pool of nitrogen, its turnover rate, and the overall rate of protein synthesis were estimated by the method of SAN Pietro and RittenBERG in three premature infants. The excretion of urea${ }^{15} \mathrm{~N}$ following the ingestion of glycine ${ }^{15} \mathrm{~N}$ closely approximated a model of nitrogen metabolism in which newly synthesized protein has a long half-life. Roughly $10 \%$ of the protein synthesized by the infants appeared to be accumulated as 'growth protein'.

The metabolic pool of nitrogen was found to be large when compared with that of normal adults $[2,5,9,14$, 18 ], and turnover rate was slower than that observed in normal adults. These findings were similar to those obtained in some states of protein accumulation in adults with endocrine disorders [5].

\section{References and Notes}

1. Glapp, W.M.; Butterfield, L.J. and O'Brien, D.: Body water compartments in the premature infant, with special reference to the effects of the respiratory distress syndrome and of maternal diabetes and toxemia. Pediatrics 29: 883 (1962).

2. Crispell, K.R.; Parson, W. and Hollifield, G.: A study of the rate of protein synthesis before and during the administration of $\mathrm{L}$-triiodothyronine to patients with myxedema and healthy volunteers using $\mathrm{N}^{15}$ glycine. J. clin. Invest. 35: 164 (1956).

3. FeE, B. A. and WeIL, W. B., Jr.: Body composition of infants of diabetic mothers by direct analysis. Ann. N.Y.Acad. Sci. 110: 869 (1963).

4. Fomon, S. J. and MAY, C. D. : Metabolic studies of normal full-term infants fed pasteurized milk. Pediatrics 22: 101 (1958).

5. HAAK, A.: Studies concerning the effects of human growth hormone and testosterone on nitrogen metabolism in man (J.J. Groen and Zoon, Leiden 1963).

6. HAwK, P.B.; Oser, B.L. and Summerson, W.H.: Practical physiological chemistry, p. 886 (Blakiston, Toronto-New York 1954).

7. Hawk, P.B.; Oser, B.L. and Summerson, W.H.: Practical physiological chemistry, p. 890 (Blakiston, Toronto-New York 1954).
8. Iob, V. and Swanson, W.W.: Mineral growth of the human fetus. Amer.J.Dis. Child. 47: 302 (1934).

9. KassenaAr, A.; de Graeff, J. and Kouwenhoven, A. T.: $\mathrm{N}^{15}$-Glycine studies of protein synthesis during refeeding in anorexia nervosa. Metabolism 9: 831 (1960).

10. Olesen, K.; Heilskov, N. G.S. and SchonheyDER, F.: The excretion of ${ }^{15} \mathrm{~N}$ in urine after administration of ${ }^{15} \mathrm{~N}$ glycine. Biochim. biophys. Acta 15 : 95 (1954).

11. Picou, D. and TAyLor-Roberts, T.: The measurement of total protein synthesis and catabolism and nitrogen turnover in infants in different nutritional states and receiving different amounts of dietary protein. Clin. Sci. 36: 283 (1969).

12. Pitts, R. F.; Pilkington, L.A. and de HaAs, J.G. M.: $N^{15}$ Tracer studies on the origin of urinary ammonia in the acidotic dog, with notes on the enzymatic synthesis of labeled glutamic acid and glutamines. J. clin. Invest. 44: 731 (1965).

13. Ritrenberg, D.: Dynamic aspects of the metabolism of amino acids. Harvey Lect. 44: 200 (1950).

14. San Pietro, A. and Rittenberg, D.: A study of the rate of protein synthesis in humans. II. Measurement of the metabolic pool and the rate of protein synthesis. J. biol. Chem. 201: 457 (1953).

15. Simon, S.: Nitrogen distribution in the urine of infants. Z. Kinderheilk. 2: 1 (1911).

16. Snyderman, S.E.; Holt, L.E., Jr.; Dancis, J.; Rottman, E.; Boyer, A. and Balis, M.E.: 'Unessential' nitrogen: a limiting factor for human growth. J.Nutr. 78: 57 (1962)

17. Sprinson, D.B. and Rittenberg, D.: The rate of utilization of ammonia for protein synthesis. J. biol. Chem. 180: 707 (1949).

18. Tschudy, D.P.; Bacchus, H.; Weissman, S.; Watkin, D. M. ; Eubanks, M. and White, J. : Studies of the effect of dietary protein and caloric levels on the kinetics of nitrogen metabolism using $\mathrm{N}^{15}$ L-aspartic acid. J. clin. Invest. 38: 892 (1959).

19. Van Slyke, D. D.; Philipps, R. A.; Hamilton, P. B.; Archibald, R.M.; Futcher, P.H. and HilLER, A. : Glutamine as a source material of urinary ammonia. J. biol. Chem. 150: 481 (1943).

20. Walser, M. and Bodenlos, L. J. : Urea metabolism in man. J.clin. Invest. 38: 1617 (1959).

21. Wu, H. and Bishop, C. W.: Pattern of $\mathrm{N}^{15}$-excretion in man following administration of $\mathrm{N}^{15}$-labeled glycine. J.appl. Physiol. 14: 1 (1959).

22. Wu, H.; Sendroy, J., Jr. and Bishop, G. W.: Interpretation of urinary and $\mathrm{N}^{15}$-excretion data following administration of an $\mathrm{N}^{15}$-labeled amino acid. J.appl. Physiol. 14: 11 (1959). 
23. Volk Radiochemical Company, Burbank, CA.

24. Similac, Ross Laboratories, Columbus, OH.

25. The author gratefully acknowledges the expert technical assistance of Mrs. Eluzabeth Zung, and expresses his appreciation to J. C. Cook, Jr., and the late IRving SUcher for the mass spectrometric analyses. He is especially indebted to Professor David Rittenberg for his help and encouragement.

26. Permission for these studies was obtained through the methods prescribed by the United States Public Health Service.
27. Supported by National Institutes of Health Research Grants nos. AM 09346 and AM 08625, and by a grant from the National Association for Retarded Children. The author is the recipient of $\mathrm{Na}$ tional Institutes of Health Career Development Award no. 1-K3-ND-14,263.

28. Request for reprints should be addressed to: J.F. Nicholson, M.D., Department of Pediatrics, College of Physicians \& Surgeons, Columbia University, 630 West 168th Street, New York, New York 10032.

29. Accepted for publication February 10, 1970. 